\title{
The Bison in Canada
}

\section{How it was Saved from Extinction and its Management Today}

By P. J. Marjoribanks Egerton

Ruthless killing by white men brought the wood, or northern, bison which once ranged from Edmonton, Alberta, north to Great Slave Lake, within sight of extinction, as it did the plains bison further south in the U.S.A. In 1893 the Canadian Government instituted a policy of conservation. Wood Buffalo Park was declared a protected area, and in 1906 the Government bought 600 plains bison in the U.S.A. and established them at Wainwright. These were so successful that twenty years later 6,000 were taken to Wood Buffalo Park. Here they interbred with the wood bison, and it was feared that the wood bison would disappear as a distinct subspecies. In 1957, however, a small isolated group of wood bison were discovered in a remote part of Wood Buffalo Park, and these are being kept separate. Miss Egerton studied the social behaviour of the North American bison while employed as a graduate student in the University of Alberta in Edmonton, Canada, from September, 1960, to December, 1962. In this paper, while mentioning some aspects of bison behaviour, she is concerned mainly with the history and present standing of the species in Alberta.

THE decline in numbers of the North American bison, following the colonisation of America by white man, is now a well known story. Not so well known is the story of the timely rescue of the species from extinction at the end of the nineteenth century, and the subsequent increase in its numbers. When white men first came to America, the bison ranged east of the Rocky Mountains from Northern Canada throughout what is now the United States. The range of the species was increasing, and it is believed that the bison would have penetrated the passes through the Rocky Mountains and reached the coastal plains in a few decades had not their numbers been so quickly reduced by man.

Although numerous fossil species of bison are recognised, only two subspecies of North American bison survive today. These are the plains bison, Bison bison bison, and the wood, or northern, bison, Bison bison athabascae. According to Soper (1941), the range of the latter was originally north to Great Slave Lake, south to the districts immediately north of Edmonton where the forest merges into parkland, east just into Saskatchewan, and west to the Rocky Mountains. The plains bison ranged north into southern Alberta, and south into Florida and Texas. The two types are distinguished by the larger size and darker colour of the wood bison, which also has a proportionately less heavy head and 
hump than the plains form. The northern bison resembles the European bison Bison bonasus more closely than does the plains form. This is interesting in view of the fact that bison colonised North America via the Bering Straits and Alaska from Asia, where an Eastern subspecies of the European bison existed until the first world war. The wood bison are probably descendants of animals which remained in the north of the American continent, while the plains form evolved from bison that moved further south.

Although, before the coming of white men, the bison supplied most of the needs of many of the Indian tribes-from food, clothing and housing to transport in the form of hide canoes-the natural increase of the bison easily outweighed the mortality due to the Indians. But in the period between the arrival of the first white men and the end of the nineteenth century, the bison were seriously reduced in numbers, slowly at first, but with increasing speed, as the result of ruthless killing by white men. At first killing was mainly for meat for explorers, settlers, and railroad builders; later it was mainly for the hides, which were shipped east in thousands and sold, for the tongues which were often the only meat taken from a carcass, and often enough merely for sport. Later still, money was made from the sale of bones from the countless bison carcasses which littered the plains. It might here be pointed out that, with the coming of agriculture on a large scale, the bison would eventually have had to go, because for various reasons the two are not compatible. But this is not the reason why bison were killed at the time, and is no defence for the senseless slaughter that occurred.

\section{The First Protected Area}

It was not until the end of the nineteenth century and the beginning of the twentieth that any efforts were made to halt the bison's decline. Protection laws were passed, but at first, from lack of enforcement, they had little effect. For example, the area in Northern Alberta that is now Wood Buffalo Park, was first declared a protected area in 1893 to protect the last remnants of the northern bison, but not until 1906 were rangers appointed to enforce the protection law, and the area was not declared a national park until 1922.

In 1906, the Canadian Government bought some 600 plains bison from a half-breed Indian who had built up a herd in Montana. These bison were transported to Lamont, near Edmonton, and later taken to an area prepared for them near Wainwright, further east. When these animals were rounded up for the move, however, some sixty or seventy could not be caught. The problem was solved by leaving them where they were and fencing round them. This area became Elk Island National Park.

By the 1920's the bison at Wainwright had increased to such an extent that they had either to be slaughtered or moved elsewhere. At that time, public feeling, revolted by the previous killing, was against slaughter, and so more than 6,000 bison were moved by train and barge to Wood Buffalo Park, and released near Fort Smith. There was a storm of controversy. The move, it was thought, might result in the swamping of the northern subspecies, and might in addition take diseases such as tuberculosis, 


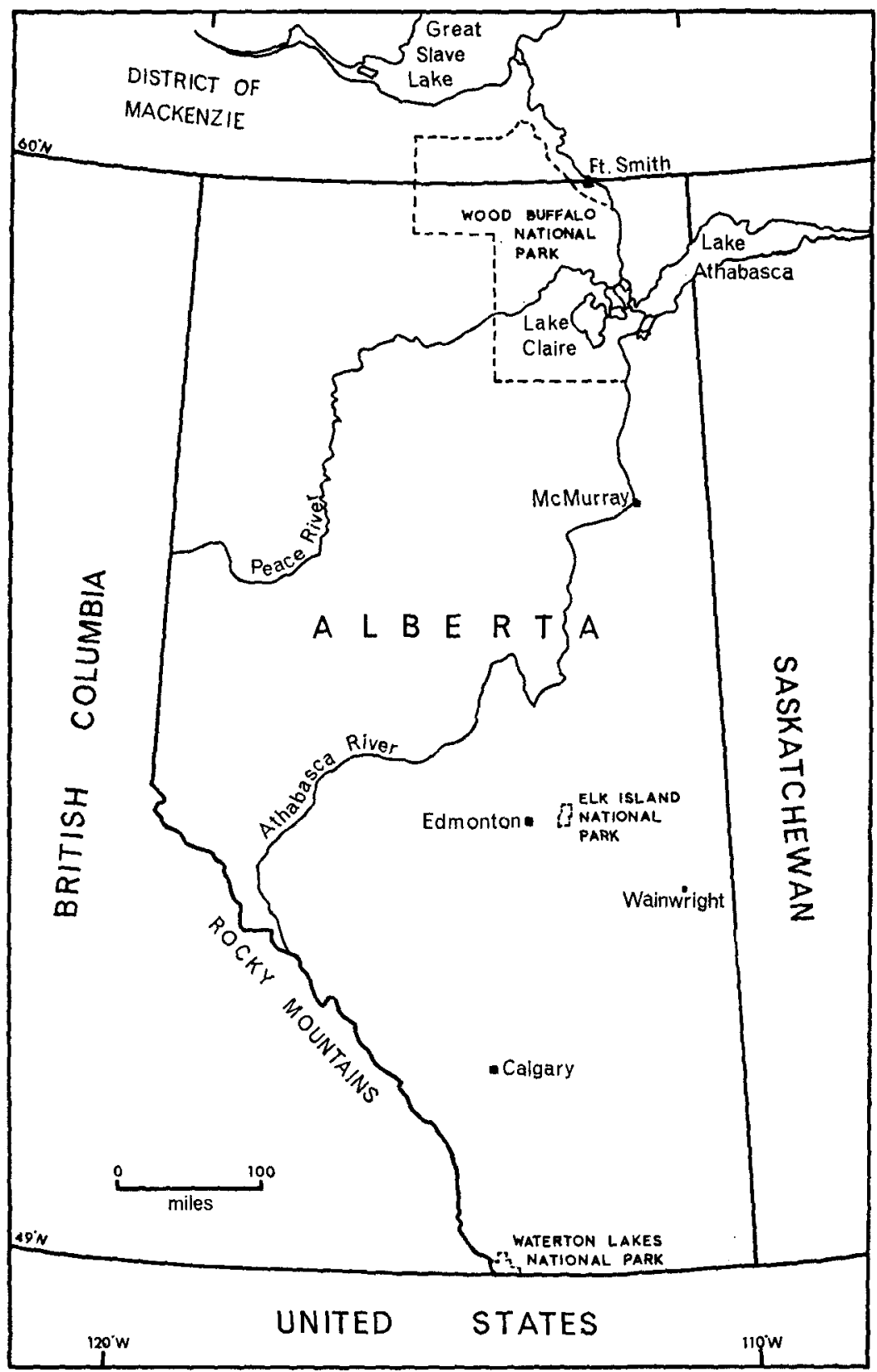


which the bison had caught from domestic cattle in the Wainwright park, into the northern area. At the beginning of the removal programme, which lasted four years, from 1925 to 1928 , it was planned to test the bison for tuberculosis first, and only move the healthy ones to Wood Buffalo Park. However, when it was found that testing was expensive, the bison were moved without testing, under the theory that the disease would not flourish in the cold northern climate. The results of this move are discussed later on. Wainwright Buffalo Park survived until 1939, when the setting up of an army camp in the area necessitated eradication of the herd. The bison in Elk Island Park remained, however, and the present population of that park is about 650. In addition to the Elk Island and Wood Buffalo Park herds, small exhibition herds are maintained in Banff National Park and Waterton Lakes National Park. The herd at Waterton Lakes was started in 1952 with bison brought from Elk Island Park, and is now kept at about twenty-five head, in an area of about 300 acres of prairie grassland.

When Wood Buffalo Park was first declared a protected area in 1893, it was estimated that not more than 500 bison still survived there. By the 1920 's, when the plains bison were introduced, the northern population was believed to have increased to about 1,500 . The introduced plains bison settled well in the area, interbred with the northern subspecies, and the numbers continued to rise. In 1926, the park, a vast unfenced area of widely varied vegetation types including spruce forest, pine forest, upland prairie and lowland delta meadows, was enlarged by nearly 7,000 square miles to its present 17,300 square miles to include some meadows in the Lake Claire area, which had been invaded by bison. This area now supports the largest concentration of bison in the park (Fuller, 1962). In 1961 the total number of bison in Wood Buffalo Park was about 10,300 , according to an aerial census (Novakowski, unpublished). This is the largest and the only truly wild population of bison in existence today.

\section{Discovery of True Wood Bison}

Meanwhile in 1957 an important discovery had been made in Wood Buffalo Park. When in the 1920's the 6,000 plains bison had been brought to the Park, many people feared that the true wood bison would disappear as a distinct subspecies, and when it was seen how freely the two subspecies interbred it was thought that the wood bison had indeed been swamped. However, in 1957, Novakowski found a few bison in the far north-west part of the park (Banfield and Novakowski, 1960), and subsequent investigations showed that these animals were isolated by inhospitable and swampy country, 75 miles from the nearest herds of hybrid plains-wood bison. In 1959 a field study showed that there were about 200 of them, and measurements of five specimens taken identified them as wood bison. It was decided to keep these animals separate from the rest of the bison in the park to preserve the subspecies, and to move some to Great Slave Lake to form the nucleus of an independent breeding herd. Corrals were built in the area, bison rounded up and tested for tuberculosis and other diseases, and, so far, after isolation and retesting, twenty have been taken by barge to Fort Providence, on Great Slave Lake, which 
appropriately is in the original wood bison territory (Novakowski, personal communication).

The first phase in the conservation of a species usually involves simply protecting it, to allow the species to build up to a safe level. For successful long-term conservation, however, protection must be combined with management. In Canada, the first phase of bison conservation has been accomplished; the second phase has now begun.

The main aims of management of a species are to conserve the species in good health for its historic and aesthetic values, and eventually to take any surplus animals for human use. For management to succeed, it is essential to find out certain things about the population. How many animals can an area support? What is the reproductive rate? What mortality factors act on the population ? If a certain number is to be taken regularly for human use, and the population kept at a constant level, then this number will be the difference between the natural increase of the population and the decrease due to the various mortality factors. For some years now, research programmes by members of the Canadian Wildlife Service and others have attempted to answer these questions as they apply to bison.

\section{Rutting and Calving}

Since Fuller (1962) gives a detailed discussion of reproduction in bison, it will only be mentioned briefly here. The rutting season in Wood Buffalo Park is in August and September, and calving in May and June, slightly later than in the southern herds. Gestation is the same as in domestic cattle, 9 to $9 \frac{1}{2}$ months. Bison cows are, in general, sexually mature at two or three years and have their first calf at three or four. There are no reliable reports of twin births in bison. The early explorers' reports of multiple births (Roe, 1951) are probably due to the fact that young calves, less than about a month old, often lie down near one another, the mother of the youngest of them grazing near her calf, while the mothers of the older calves graze further away (Marjoribanks Egerton, unpublished M.Sc. thesis, 1962). A small proportion of bulls have been shown to be sexually mature at one year, but most are not mature until three (Fuller, 1962). It is unlikely, however, that in the wild they breed at less than five years.

During the rut, bison in Wood Buffalo Park are mostly in herds of fifteen to twenty-five animals, including three or four adult bulls and about ten adult cows, the rest calves, yearlings and two-year-olds. There are also numerous adult bulls which wander alone. It is generally believed that these bulls are driven out of the herd by a master bull in each herd or "harem" and that they can be considered as surplus animals from the point of view of reproduction in the population. There is evidence, however, to show that this is not true, that these so-called solitary bulls actually play an important part in the rut, and that there is no regular " harem-master" bull (Marjoribanks Egerton).

The upper age limit of fertility in bison is not known. Probably few live long enough in the wild to reach infertility due to age. It is interesting that at the slaughter of the Wainwright herd in 1939, a pregnant cow was found bearing a mark that showed she was one of the original members 
of the herd purchased in Montana in 1906. She was thus well over thirty years old. A study of the reproductive physiology of bison is at present being conducted in Wood Buffalo Park by Dr. N. S. Novakowski, a Canadian Wildlife Service biologist. Two male and two females are taken each month, the reproductive organs being taken for study and the jaw-bone for ageing. Although most calves in the park are born in May and June, the occasional new-born calf is seen in each month of the year. From the study it is hoped to find out what proportion of bulls and cows are fertile at different times of year, and to explain the occurrence of calves out of the normal season.

Limiting factors in bison, apart from mortality caused directly by man, are of two kinds : those due indirectly to man's influence, and those due to natural causes. Examples of the first are a limited food supply caused by keeping bison in fenced areas, and diseases contracted from contact with domestic animals ; while wolf predation and death caused by climate and catastrophes are examples of the second type.

In different areas, different limiting factors will be important. In small, fenced parks, food supply is probably the most important factor. In Waterton Lakes Park, for example, the area is limited to about 300 acres, and while the herd is kept down to about twenty-five head by periodic slaughter, some artificial winter feeding is still necessary. In Elk Island Park, where in addition to bison there are other large ungulates-moose Alces americana (related to the European elk, $A$. alces), elk (wapiti) Cervus canadensis (related to the European red deer $C$. elaphus), whitetail deer and mule deer-in a fenced area of about 50 square miles, food supply is again an important limiting factor. In this park, however, tuberculosis exists in the bison herd, and so while some animals must be removed regularly anyhow, because of the limited food supply, the slaughter is combined with a programme of testing the bison for tuberculosis. By selective killing of the reactors, the disease is controlled at the same time as the population is kept within the limits of its food supply. In Wood Buffalo Park, where the area is so large that food supply is not limited to the same extent as in fenced parks, the population is limited by mortality due to disease, drowning, and, to a small extent, wolf predation.

Tuberculosis was brought into Wood Buffalo Park in the 1920's with the introduction of the plains bison. The disease did not die out as had been hoped, and in 1947 Fuller (1962) found a high incidence of the disease in bison in this park. He estimated that tuberculosis was probably the highest single regular mortality factor, accounting for the death of between 4 and 6 per cent of the population each year. Brucellosis (contagious abortion) was diagnosed in Wood Buffalo Park in 1956 (Fuller, 1962) although it probably existed in the park before that time. This disease affects the population by lowering the birth rate.

Since the discovery of tuberculosis in Wood Buffalo Park, a programme of control has been in operation there. Annual round-ups have been held since 1952 either at the Hay Camp, 40 miles south of Fort Smith, or at Sweetgrass, the Buffalo Management Camp near Lake Claire, and large numbers of bison have been tested for tuberculosis. The herds are rounded up, using a helicopter, light aircraft, ground vehicles, and horses. 


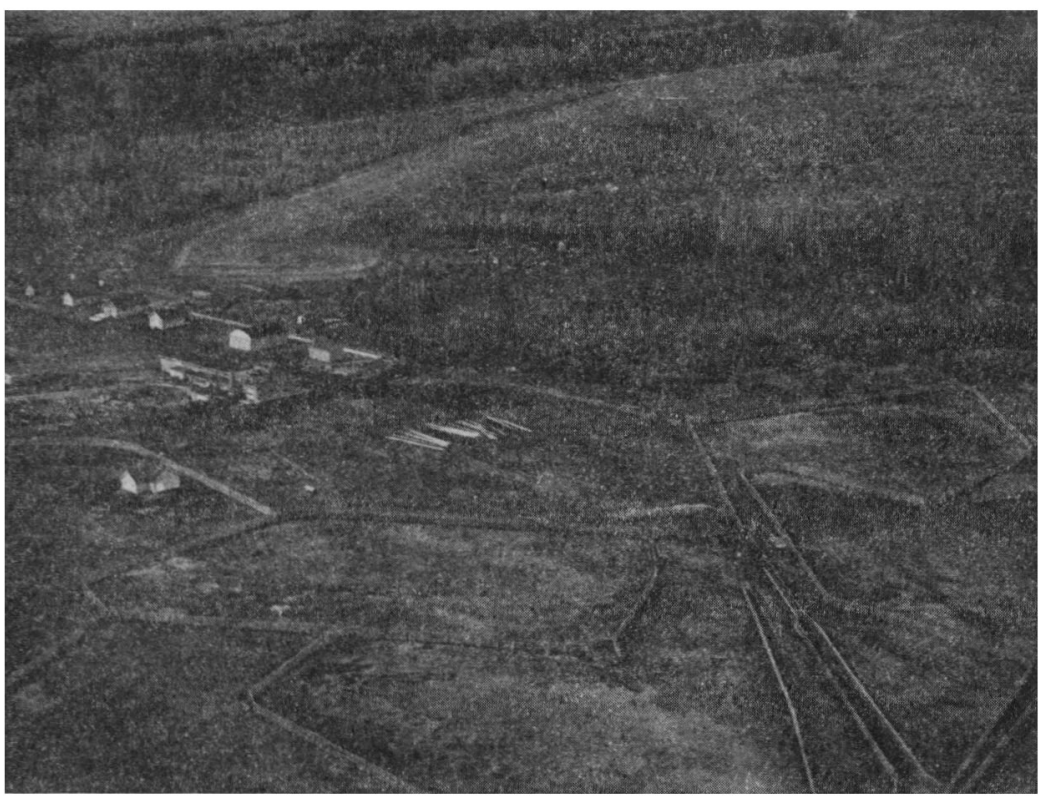

Aerial photograph of Sweetgrass Buffalo Management Camp, showing the landing strip, some of the corrals, the chute and squeeze (bottom right) and the abattoir (on right of the group of buildings).

A large area of corrals has been built at Sweetgrass, where the round-ups were held between 1957 and 1961, and bison are held for a few weeks while the testing and slaughter are in progress. Supplementary feeding with hay is necessary during this time, because there is not sufficient grass in the corrals for so many bison for such a time. This is the only time that supplementary feeding is practised in Wood Buffalo Park. Since testing for tuberculosis involves injection and subsequent blood sampling, it is necessary to be able to immobilise each animal. For this purpose a wooden chute and squeeze of the sort used in dealing with cattle has been built (see photograph). On injection, each animal is marked with a numbered ear tag to allow identification when the blood sample is taken. Reactors are killed and non-reactors released. In this way it is hoped that the incidence of tuberculosis in the northern herds can be kept at a minimum. Young animals are now also injected against brucellosis.

A recent outbreak of anthrax among bison herds just outside the Wood Buffalo Park boundary caused great concern. Fortunately, the area infected is separated from the park area proper by the Little Buffalo River, on the east boundary of the park. Extensive efforts were made at the time of the outbreak to prevent any bison crossing the river into the park. All carcasses were burned and buried, and efforts were made to burn off an area of land to destroy the anthrax spores. Control measures are still in operation to prevent the disease, which has caused the death of more than 500 bison, from spreading into the park (Novakowski 1963, pers. comm.). 
This fatal and highly infectious disease could have a disastrous effect on a population of herd animals such as bison.

In an investigation into the effects of wolf predation on bison in Wood Buffalo Park, Fuller (1962) showed that almost all predation was on aged animals, young calves, or animals crippled or handicapped by disease. Even within these classes, predation was not severe. Removal of crippled or aged animals could not be said to have a detrimental effect on the bison population, and since not all calves are needed to maintain the population level, the removal of a few by wolves need not give cause for concern.

Since much of Wood Buffalo Park lies in the delta regions of the Athabasca and Peace Rivers, flooding of large areas of bison habitat is a fairly common occurrence. Drownings due directly to flooding and to bison falling through thin ice have been reported regularly (Fuller, 1962). Extra severe flooding has occurred several times in recent years, however, and large numbers of bison have been drowned. Flooding of the Lake Claire meadows in the autumn and winter of 1960-61, for example, caused the death of more than 2,000 animals. Thus while tuberculosis is probably the most important regular mortality factor in Wood Buffalo Park, in some years drowning surpasses all other causes of death.

\section{Drugs to Immobilise Buffalo}

The annual rounding up of large numbers of bison provides an excellent opportunity for the biological study of the animals-an opportunity which is being made good use of in Wood Buffalo Park. Experimental tests of the effects of various immobilising drugs have been conducted to discover the sizes of dose necessary. Preliminary tests on tubo-curarine showed that different animals reacted unpredictably to the drug. A dose which had no apparent effect on one animal could keep another of similar age and weight unconscious for half an hour or more. This could have serious results if the drug were used in winter, because in the cold northern climate an animal immobilised for that length of time might freeze. The best and safest drug thus far used has been Trilafon, a tranquilliser which produces a general depression in activity and which does not affect nerve function as do the others (Novakowski, personal communication, 1963).

At the same time as the tuberculin test and injection against brucellosis are carried out, the bison are branded with the year number and with an initial to show where they were captured. This is to obtain information on herd movements within the park, and, in the case of calves, serves later as confirmation of the age of the animal. Age can be ascertained by tooth development only to the age of four years (Fuller, 1959). Branding of calves is now regularly done in many parks in both Canada and the United States, the accurate age determination that it allows being essential to proper population analysis.

Now that the numbers of bison have increased through careful conservation in the last fifty years, they can safely be used as a source of human food without endangering the species. Bison are now " harvested" in two ways : through the periodic slaughters held in Elk Island and Wood Buffalo Parks, and through a small amount of hunting that is permitted along the Wood Buffalo Park boundaries. The slaughters are conducted 
F. W. Champion

Plate 15 : “With velvety step and undulating movements..." Indian tiger on the trail at night, from Cats of the World, by Armand Denis, reviewed on page 319.

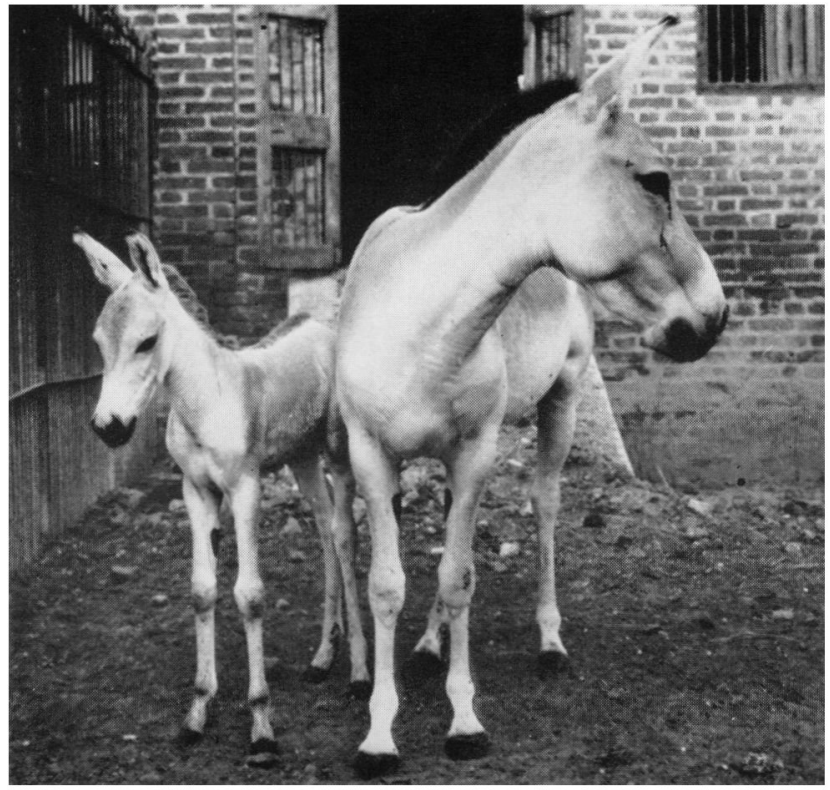

INDIAN WILD ASS AND FOAL

Rarely bred in captivity, the Indian wild ass is on the IUCN list of endangered species. The foal was born on August 13th, 1964, in the Maharajah Fatesingh Zoo at Baroda. The photograph was sent by H.H. the Maharajah of Baroda, who is a member of the FPS. 


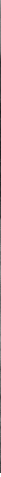

Plate 17 : Bison in a hurry in Wood Buffalo Park.

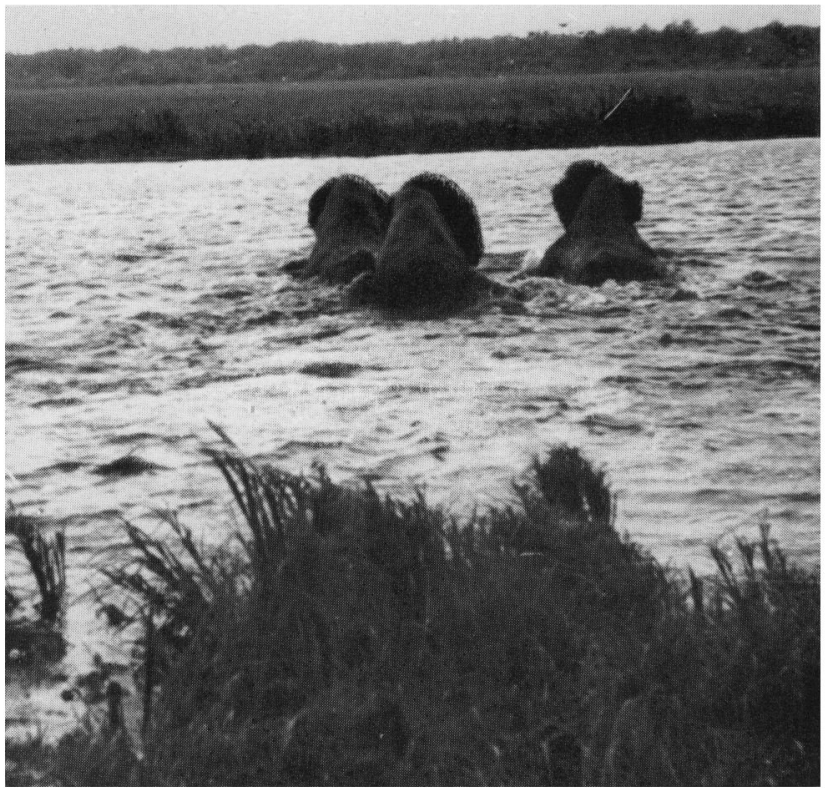

\section{BISON IN CANADA}

Photographs by

P. Marjoribonks Egerton.

Plate 18 :

Three bison bulls wading across a slough in Wood Buffalo Park. 


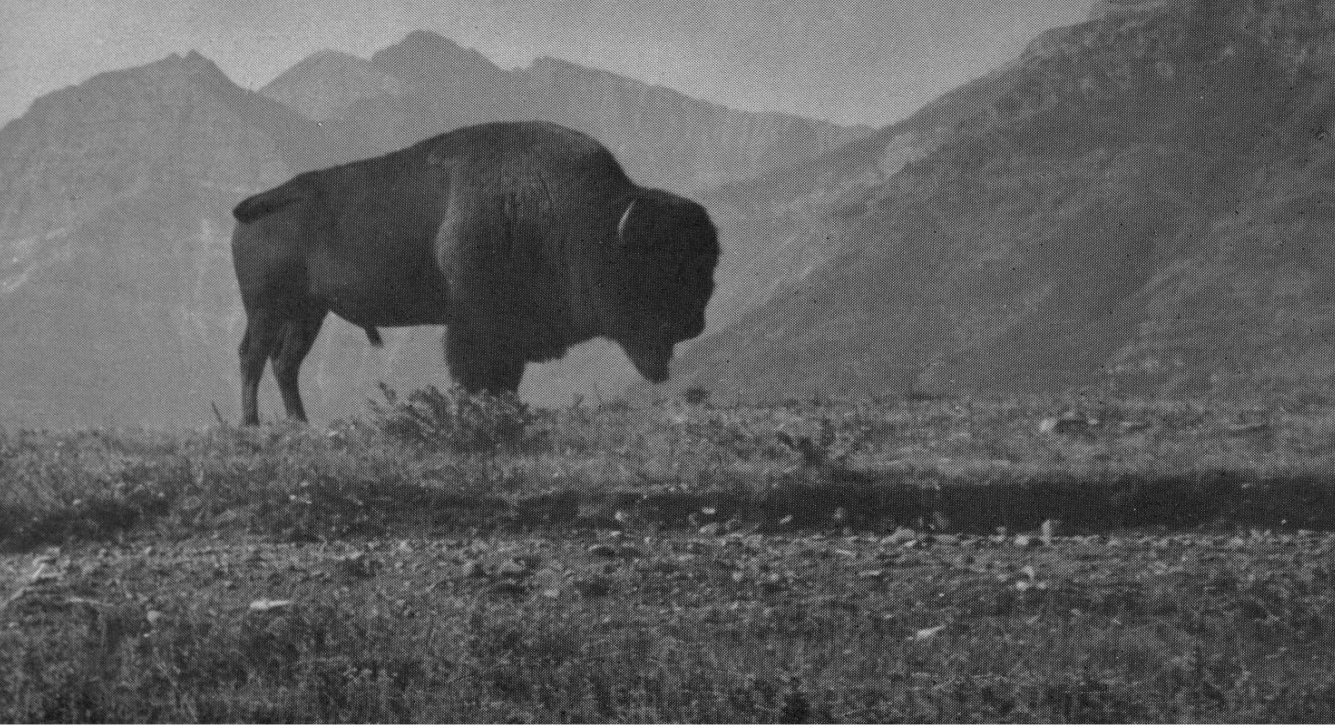

Plate 19 : Bison bull.

\section{IN WATERTON LAKES PARK}

Plate 20 : Cow and calf.
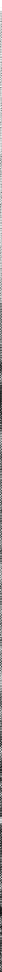


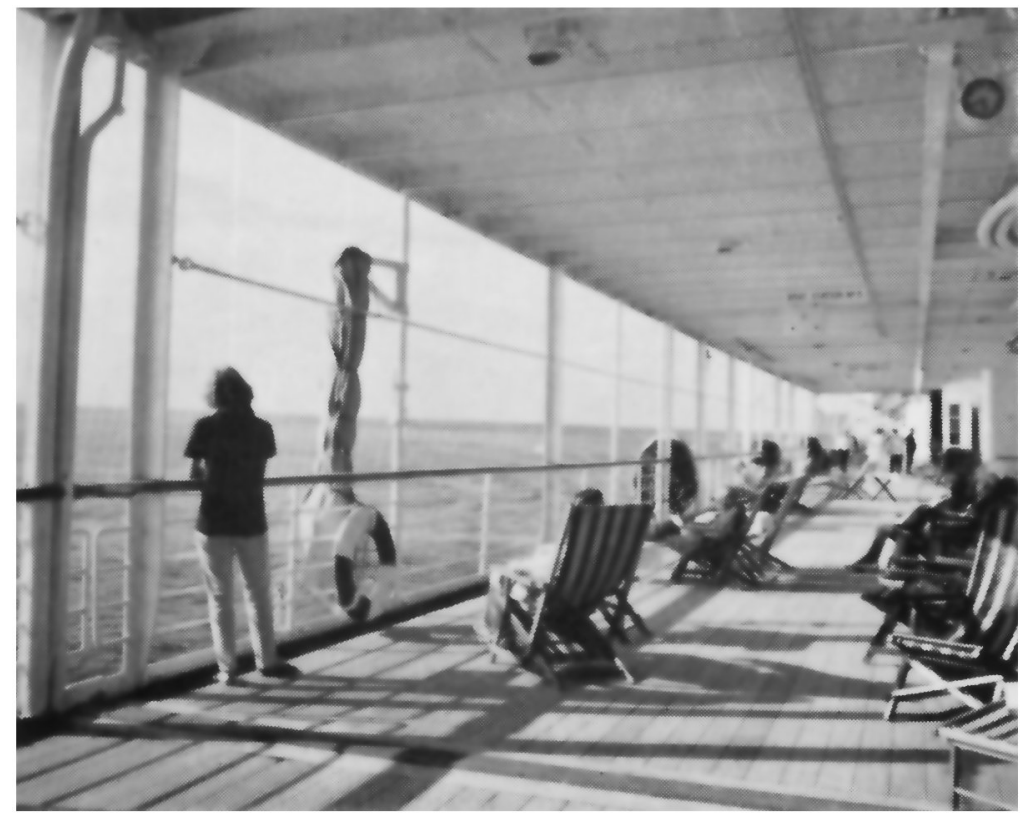

\section{TO SOUTH AFRICA AND BACK IN SUNSHINE AND SMOOTH SEAS}

Union-Castle's big mailships (up to 38,000 tons) sail every Thursday from Southampton to the Cape. Thirteen and a half days to Cape Town. To make a 43-day sunshine-and-smooth-seas cruise of it, many people travel on round the coast to Durban, using the ship as their hotel at ports of call. Then back round the coast and home to Southampton. In November, when reduced Holiday Tour fares apply, you can do the round trip First Class from about $£ 280$, or Tourist Class from about $£ 180$ in December.

Union-Castle Sea Safaris offer all-in trips, out and back by sea, and anything from 9-30 days travelling inland in Southern Africa. Sea Safaris include visits to the most famous Game Parks and Reserves. Hluhluwe, Kruger National, the Zambesi, Nairobi, Amboseli, Ngorongoro, Lake Manyara, Queen Elizabeth, Murchison Falls. Take your camera!

Full details from Union-Castle, 19.21 Old Bond Street, London W.1. HYDe Park 8400 .

\section{the going's good by UNMON-CASTLE The big ship way to Africa}


with efficiency and the meat is carefully inspected and graded in modern abattoirs. (In all but advanced cases, the meat from tubercular reactors is perfectly safe for human consumption.) Some of the meat is sold to the general public via supermarkets throughout Canada, but most of it is distributed to the North American Indians. Tanned bison hides from Elk Island Park are sold to the public, at prices between $\$ 30$ and $\$ 45$ (about $£ 10$ to $£ 15$ ). The Industrial Division is investigating the commercial possibilities of such items as the horns and hoofs.

Experiments in crossing bison and domestic cattle have been conducted for many years at experimental farms in Alberta, in the hope that a breed of cattle could be produced combining the hardiness of bison with the meat-producing qualities of the domestic breeds. The special object in view was to establish a breeding herd of the hybrids for economical beef production in the northern regions of the Prairie Provinces. It was hoped that bison hybrids would thrive better in the severe winters of these regions than do domestic cattle. Numerous problems were encountered, however. The chief of these was that the male hybrids were found to be infertile in almost every case. In addition many cows died at parturition and many calves were lost through abortion (Deakin, Muir and Smith, 1935). Although the hybrids (known as cattalo) were found to be hardier than domestic cattle (Peters, 1955), they were less satisfactory as beef animals, the weight gain being slower and the carcass grade lower as the proportion of bison breeding in the hybrids tested increased (Peters, 1958). Sufficient variation between individual animals was found, however, to warrant further experiments to improve the breed by selection.

For obvious reasons bison and agriculture are incompatible. If bison were allowed to roam free in agricultural areas they would compete for grazing with domestic cattle and damage fences and crops; also there would be the risk of them interbreeding with domestic cattle, with the consequent production of unsatisfactory hybrids and losses among domestic cows. Their nuisance value would lead farmers to shoot them and probably eliminate them altogether. Thus, except where they are kept on farms for a specific reason, bison cannot be allowed free in agricultural areas, and can only survive in future in protected areas especially set aside for them.

The bison illustrates, perhaps more vividly than does any other species, a story of excessive exploitation by man ; of catastrophic decline followed by rescue from extinction; of protection, at first rather haphazard and unscientific, followed by successful planned management. The species as a whole is now well above the danger level. It is being managed on a sustained yield basis, and detailed studies of every aspect of its biology are in progress.

\section{Acknowledgments}

I should like to thank those members of the University of Alberta who made my study possible, and particularly Dr. S. A. Altmann and Dr. W. A. Fuller who supervised my research programme. I am also very grateful to the following members of the National Parks staff whose help made the field work possible: F. Camp and R. W. Thompson (Waterton Lakes Park); B. E. Olson and K. F. Cooper (Wood Buffalo Park); H. R. Webster 
and W. D. Armstrong (Elk Island Park). The project was financed by a teaching assistantship and a grant from the University of Alberta, and by a bursary from the National Research Council of Canada.

\section{Literature Cited}

Banfield, A. W. F., and N. S. Novakowski, 1960. The survival of the wood bison (Bison bison athabascae Rhoads) in the Northwest Territories. National Museum of Canada, Natural History Papers, 8, Aug., 1960.

DeAKIN, A., G. W. MuIR, and A. G. Smith, 1935. Hybridisation of domestic cattle, bison and yak. Canada Dept. of Agric. Technical bulletin, 2.

FULLER, W. A. 1959. The horns and teeth as indicators of age in bison. F. Wildl. Manag. 23 (3), 342-344.

FULLER, W. A., 1962. The biology and management of the bison of Wood Buffalo National Park. Canadian Wildlife Service. Wildlife Management bulletin. Series 1, 16, 52 .

Peters, H. F., 1955. Range Experimental Farm, Manyberries, Alberta, Progress Report, 1948-1953.

Peters, H. F., 1958. A feedlot study of bison, cattalo and Hereford calves. Canadian F. of Anim. Sci. 38, 87-90, June, 1958.

RoE, F. G., 1951. The North American Buffalo. Univ. of Toronto Press. SOPER, J. D., 1941. History, range and home life of the northern bison. Ecol. Monogr. 11, 347-412.

\section{TWO GREAT RARITIES}

$\mathrm{O}^{\mathrm{N}}$ N March 15th, 1963, Dr. H. Elliott McClure caught a striking little red-headed thrush in a mist net, 6,660 feet up on the peak of Mt. Brinchang in the Cameron Highlands in Malaya. It could not be identified, and after being colour photographed, measured and ringed it was released. The colour photograph is reproduced in black and white on Plate 13, opposite page 297. The experts were nonplussed by the bird. After some difficulty it was eventually identified in the British Museum by Dr. I. C. J. Galbraith as the rufous-headed robin Luscinia ruficeps, of which only three specimens had ever been recorded. These had all been taken in 1905 in the Tsin-ling Mountains, in central China, sent to Tring and described by Hartert in 1907. They are now in the American Museum of Natural History in New York. The rufous-headed robin, writes Dr. McClure in the Malayan Nature Fournal, is certainly " one of the rarest birds in the world ". The head and neck are bright orange-rufous, with white throat, broad black stripe under the eyes and round the throat, and slate-grey back and rump.

The other rarity, reproduced on Plate 14, opposite page 297 , by kind permission of Animals, is a fish that until last year was known only by one specimen captured near Durban and also a painting, done in Mauritius about 1870 by the American consul, Nicolas Pike. From this painting Professor J. L. B. Smith named it Lepidaplois albomaculatus, and described the first specimen captured near Durban, which died before he saw it, as "the greatest find since the coelacanth". He urged Dr. H. J. A. Wright, an amateur skin diver in Durban who told him of it and who specialises in hunting for rare fish, to find another. Dr. Wright spent many anxious hours searching before eventually, on Boxing Day, 1963, he found one lurking in a deep rock cavity, 20 feet down. After some anxious manoeuvring he managed to get it in his net. It proved to be a juvenile and since then he has caught another juvenile and seen an adult. 